Portland State University

PDXScholar

$10-2019$

\title{
Twenty-First Century Book Studies: The State of the Discipline
}

\author{
Rachel Noorda \\ Portland State University, rachel.noorda@pdx.edu \\ Stevie Marsden \\ University of Leicester
}

Follow this and additional works at: https://pdxscholar.library.pdx.edu/eng_fac

Part of the Creative Writing Commons, and the English Language and Literature Commons Let us know how access to this document benefits you.

\section{Citation Details}

Noorda, R., \& Marsden, S. (2019). Twenty-First Century Book Studies: The State of the Discipline. Book History 22, 370-397. doi:10.1353/bh.2019.0013.

This Post-Print is brought to you for free and open access. It has been accepted for inclusion in English Faculty Publications and Presentations by an authorized administrator of PDXScholar. Please contact us if we can make this document more accessible: pdxscholar@pdx.edu. 
Title of paper Twenty-First Century Book Studies: The State of the Discipline

Journal: Book History

Authors: Marsden, S. L.; Noorda, Rachel

Status: Accepted

Date of acceptance: 05 Jun 2018

\section{Twenty-First Century Book Studies: The State of the Discipline}

\section{Introduction}

During the 25th annual Society for the History of Authorship, Reading and Publishing (SHARP) conference in 2017, held at the University of Victoria, Canada, Stevie Marsden and Rachel Noorda moderated a workshop on the topic of "The Twenty-First Century Book." Six scholars (Beth Driscoll, Per Henningsgaard, Simone Murray, DeNel Rehberg-Sedo, Simon Rowberry and Claire Squires), whose research is predominantly positioned within the twenty-first century, were invited to discuss the challenges and opportunities for study of the twenty-first century book. The 2017 SHARP conference, "Technologies of the Book", seemed the perfect setting to hold this workshop. Not only did the conference theme complement many of the twenty-first century book subjects discussed during the workshop, but as it was SHARP's 25th annual conference, it was imbued with reflection on the society's past twenty-five years and the community of scholars it has developed. Indeed, SHARP membership data indicates that many of its members are interested in twenty-first century research and scholarship: thirty-four percent of SHARP members who indicated a historical period in their membership data listed the twenty-first 
century as a period of interest, either as an exclusive historical period of study or alongside other periods, particularly the twentieth century. Thus twenty-first century book research is a significant area of SHARP research and a period of study that interests a growing group of SHARP members. However, the discussion of twenty-first century book research held during the workshop indicated that there was a need for a fuller examination of the state of the discipline of the twenty-first century book. Accordingly, this article will explore and examine current trends, themes and critical discourse related to the twenty-first century of the book in order to explicate the current state of twenty-first century book studies.

However, before considering the status of twenty-first century book studies and its place in the book history field and timeline, definitions are needed for three terms: publishing studies, book history, and twenty-first century book studies. We have singled out these terms for explicit definition for two reasons. Firstly, they are commonly used, or referred to, in much of the academic literature we will be discussing herewith but their definitions can at times be contested. Therefore, it is important for us to clarify how we are using them throughout this article. Secondly, as these terms are commonly used together, and sometimes analogously, definitions are important in delineating their relationships with each other.

Publishing studies has been used to describe academic research of the contemporary book industry (primarily post-1960s conglomeration) ${ }^{\mathrm{i}}$; descriptive industry reports that largely fail to incorporate theoretical frameworks and historical context ${ }^{\mathrm{ii}}$; or as a catch-all term for the study of forms, mediation, content, markets, and the connection between past and present in the life of books. ${ }^{i i i}$ Even scholars who use the term publishing studies have described it as an "ill-defined 
premise",iv that is unclear and underdeveloped, "far from neutral" and which carries "untoward implications"v. The term publishing studies is prevalent in the United Kingdom and Australia particularly ${ }^{\mathrm{vi}}$, which makes publishing studies a foreign (or at least little-known) concept and discipline in almost all other parts of the world. For example, Noël has argued that '[i]n France, like in most countries, there is no such thing as a unified sub-field addressing book publishing or "publishing studies". vii Because of the geographically limiting and "indeterminate"viii nature of publishing studies, its usefulness and purpose as a term is highly restricted. Therefore, despite the prevalent use of the term in seminal works such as Simone Murray's mapping the work of twenty-first century book studies (which will be discussed in more detail presently), the problematic and variable nature of the term prompts this article to relinquish publishing studies in search of more descriptive and precise vocabulary.

The second key term we want to elucidate for this article is book history. In at least some of the definitions and understandings of the term publishing studies, there is a relationship with the field of book history. Darnton called book history "the social and cultural history of communication by print" and in terms of timeline, Darnton asserted that book history "concerns books since the time of Gutenberg., ${ }^{\text {ix }}$ Developing this, Henningsgaard describes book history studies as:

[A]ll those aspects of the book that have historically been seen as incidental to the main purpose of the book, which is to transmit ideas, but in fact crucially inform this process. Furthermore, the "book" portion of "book history" has been broadly interpreted to include "the entire history of written communication," rather than merely those objects we (presently) commonly identify as comprising this category of "the book"

In other words, book history is an exploration of the role of the book and its processes. Indeed, this very journal defines book history as "the history of the creation, dissemination, and reception 
of script and print,"xi which covers a wide range of topics, even more so with the technological and cultural developments of the twentieth and twenty-first centuries which have seen radical changes to the production, dissemination and transmission of ideas.

However, the "history" portion of "book history" has, at times, dominated understandings of this term, making the development of contemporary research of the book appear anomalous to the field. By its very nature, history, and our conception of it, is inherently related to incidents and happenings of the past, but there is a debate, particularly in studies of the book, as to how long ago these past events need to have occurred before they warrant examination and study. If we are to accept Darnton's claim that book history pertains to study of the book "since the time of Gutenberg," we must also accept that this includes recent history up to, and including, the present day. Twenty-first century book studies corresponds with a growing gravitation in historical research toward recent history. This approach has been variously defined but is typically considered to be "histories of events that have taken place no more than forty years ago."xii Many methods used by twenty-first century book historians are aligned with recent history methods, including oral testimony and new media sources, such as social media platforms. When discussing the validity of Twitter as a recent history source, for example, Gary Osmond notes: "For those of us who can imagine the value and potential of any account of any past, however temporally measured, tweeted observations, musing and comments are a valid research source." ${ }^{\text {xiii }}$ For this reason Twitter and other social media have been described as "a first draft of the present" since these platforms offer data that presents "history-as-it-happens."xiv The utilization of such recent history methods are central to many twenty-first century book studies. ${ }^{\mathrm{xv}}$ 
This article argues, therefore, that far from being an outlier, twenty-first century book research has much in common with other centuries of study within book history, particularly if we consider the critical and methodological framework of recent history. Scholars of the twentyfirst century book have readily built upon book history models, including Darnton's communications circuit as evidenced by Claire Squires' and Padmini Ray Murrray's "Digital Communications Circuit" 2013 $3^{\mathrm{xvi}}$. Additionally, as Chartier argued, our understanding of texts, processes and reading historically can inform research of texts, processes, and reading contemporarily: "understanding and mastering the electronic revolution of tomorrow (or today) very much depends on properly situating it within history over the longue duree." ${ }^{\text {"vii }}$ Similarly, Eva Mroczek argues that twenty-first century book research can inform understanding of past forms and processes. ${ }^{\text {xviii }}$ Such a longitudinally approach to understanding the twenty-first century book is advantageous because knowing where the book has been can illuminate and reposition where the book presently is, and the twenty-first century book requires us to reexamine the very nature and definition of the book in light of its digital forms.

To encapsulate the study of recent book history within book history more broadly, this article presents, and favours, the term twenty-first century book studies. Moreover, since many of the events that have most clearly impacted the development of the book in the twenty-first century occurred in the late twentieth century this article suggests that calling this area the "long twentyfirst century" is most appropriate since, although twenty-first century book studies focus primarily on the production and consumption of texts since 2000, this year 2000 line is a blurry 
one that bleeds into the late twentieth century. For example, the largest online book retailer, Amazon.com, began operating in 1995. ${ }^{\text {xix }}$ With significant implications and disruption to previous book production and consumption processes, Amazon.com has had a near constant presence in discussions of publishing and book culture ever since. Additionally, Amazon's dominance in online bookselling has only been possible because of the creation of the World Wide Web in the late 1980s; beyond Amazon, the internet has changed the book publishing environment in manifold ways, including the opportunity for authors and publishers to connect with communities of readers online. ${ }^{\mathrm{xx}}$ The 1990s also saw the fall of the Net Book Agreement in the United Kingdom, a policy that had governed bookselling for nearly a century. ${ }^{x x i}$ Furthermore, the twenty-first century book exists in the post-conglomeration period that began in the 1960s and drastically changed the book industry by further polarizing company size, resources, and market share, with the multinational media conglomerates at one end of the spectrum and small independents at the other. ${ }^{\text {xii }}$ Finally, the long twenty-first century encompasses the reimaging and redefining of the book in light of its digital manifestations, particularly with the introduction of the ebook in the 1970 s and its growth with designated e-readers in the mid-to-late 2000 s. ${ }^{\text {xiii }}$ It should also be noted that the twenty-first and late-twentieth centuries share many characteristics and events, making it nearly impossible to disentangle the two. Thus, the "long twenty-first century" serves as a term to encompass the study of the book in its contemporary (meaning latetwentieth and twenty-first century) manifestations and environments.

Since we are positing that long twenty-first century book studies should be considered a period of book history, this article assesses the current state of the long twenty-first century book and how this particular area of book history has developed since the turn of the millenium. The purpose of this article is three-fold. Firstly, it is written in response, and to update and 
complement, Simone Murray's 2006 article, "Publishing Studies: Critically Mapping Research in Search of a Discipline", which surveyed the beginnings of academic discourses considering twenty-first century book publishing and its role as an academic discipline within universities. In her article, Murray argues for a more concerted differentiation of publishing studies as a discipline and, while acknowledging its obvious synergies with book history, identifies five research categories, or "nodal points" ("industry research and vocational information; [...] memoirs, autobiographies, biographies and house histories; the history of the book; communication, media, cultural studies and sociology; and nationalist and post-colonial studies"), under which most contemporary twenty-first century book studies research would fall. ${ }^{\text {xiv }}$ The second aim of this article is to assess the academic literature that has emerged since Murray's article was published and consider how contemporary long twenty-first century book studies scholarship has developed over the past 10 years, particularly with regards to the twentyfirst century book. Since Murray's article comments on studies of the book in the late-twentieth century and first seven years of the twenty-first century, this article will consider how the field has developed over the past decade, positioning more recent scholarship in relation to that highlighted by Murray whilst also looking forward to what the future of the discipline may be. Finally, this article posits new themes, or nodes, by which developments in academic research of the twenty-first century book can be traced and proposes new ways by which this particular area of book history may be addressed. Indeed, this article should be considered as a contribution to the ongoing conversation of how we position studies of the book and publishing in the past, present and future. 


\section{The Origins of (Long) Twenty-First Century Book Studies}

As previously noted, while this article argues that the study of the twenty-first century book begins with the turn of the century in 2000, the beginnings of this area of research can be found in the late-twentieth century, specifically post-1960s. As several scholars have identified, vocational book courses and programs began to emerge in the mid-twentieth century and flourished in the 1970s and 1980s in the UK and United States $\left.{ }^{\mathrm{xxv}}\right)$. However, higher education publishing programs also emerged in Canada ${ }^{\mathrm{xxvi}}$, Australia ${ }^{\mathrm{xxvii}}$, Ghana, Nigeria, Kenya ${ }^{\mathrm{xxviii}}$, and South Africa ${ }^{\mathrm{xxix}}$, during the late twentieth century. These vocational programs sought to impress on students an essential set of practical skills which would enable them to pursue a career within the publishing industry, seeking to replace the historically "accidental" introduction into the industry with "sound academic preparation." ${ }^{x x}$ The emergence of these programs in part gave eventual rise to the academic area of twenty-first century book studies; thus, the fact that twentyfirst century book research arose from the musings of industry professionals and descriptive, rather than critical, reports of the dynamics of the industry ${ }^{\mathrm{xxx}}$, has meant that this area of research (and of book history) has taken longer to gain recognition as critical scholarship. However, as this article demonstrates, over the past seventeen years examinations of the twentyfirst century book, and the cultural, economic, social and political contexts it exists within, have grown. This demonstrates that not only is this a particularly fruitful area of academic research, but that the nearly two decades of research that exists has firmly established long twenty-first century studies of the book within the wider context of book history. 


\section{Mapping the Discipline so Far}

As noted, part of the purpose of this article is to assess the critical literature related to the twentyfirst century book that has emerged since Murray's 2006 article "Publishing studies: Critically mapping research in search of a discipline", which identified key nodes by which long twentyfirst century book studies scholarship could be categorized. For the purposes of this study, we are interested in reassessing the five nodes established by Murray, identifying the literature that has appeared since the publication of her article, and expanding the nodes to include areas of research which are key to long twenty-first century studies of the book.

However, before moving to a literature review of twenty-first century book research since 2006, it is worth briefly discussing the prominent peer-reviewed journals which explicitly publish long twenty-first century book research: Publishing Research Quarterly, Logos, Book 2.0, and The International Journal of the Book. Publishing Research Quarterly is an American journal founded in 1985 while the British journals Logos and Book 2.0 were founded in 1990 and 2011 respectively. The International Journal of the Book (founded in 2002) aims for an international focus and was founded by Australian Common Ground Publishing. In his 2007 analysis of these journals, Miha Kovač identified key research areas evident in Publishing Research Quarterly and Logos within the time period of articles published between 2003 and 2006. ${ }^{\text {xxxii }}$ Kovač found that Publishing Research Quarterly articles were focused on national book industries, American book publishing controversies, and technological and organizational changes that were

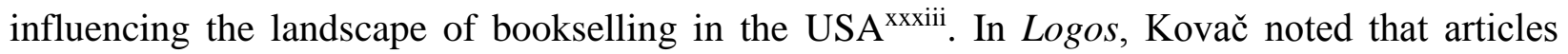
were focused on what leading people in the publishing industry had learned from their experience, literature reviews and book lists around various aspects of publishing, and the future 
of the book in the digital environment. ${ }^{\text {xxiv }}$ In addition to these four journals, there are others that are more trade-focused (and less academic) and those with a scope that remains related to, but expands beyond, the twenty-first century book. Learned Publishing and recently launched UCLbased postgraduate journal Interscript fall into the first category, while media studies journal Convergence and book history journal Book History belong to the second.

Now that the publishing avenues through which long twenty-first century book research streams have been briefly introduced, how might this research be categorized? Some scholars have attempted to offer overarching long twenty-first century book overviews and theories, either by creating their own models or adapting existing models for long twenty-first century book research. As aforementioned, Squires' and Ray Murray’s "Digital Communications Circuit”xxxv revises Darnton's Communication Circuit (1982) ${ }^{\mathrm{xxxvi}}$ for twentieth and twenty-first century book publishing practices. In this new model, new players are added (literary agents, pre-press companies, wholesalers and distributors), the changing definitions of existing players noted (such as "bookseller" to "retailer"), and the growing importance of particular players highlighted (freelancers and outsource agencies, for example). Other scholars have adapted sociology models, particularly concepts proposed by Pierre Bourdieu, for the twenty-first century book, including John Thompson's Merchants of Culture (2010) in which Thompson's overview of the twenty-first century book industry in the UK and US is based on Bourdieu's concepts of 'fields' and five different categories of value/capital. Possibly the most robust attempt to offer a new model and overarching theory for the study of the twenty-first century book is Michael Bhaskar's The Content Machine (2013) which proposed conceptualizing the twenty-first century book as consisting of content that is framed according to a model and then filtered and amplified. .xxvii $^{\text {. }}$ 
These models and overviews offer interesting perspectives on the twenty-first century book and there is a need for more critical discourse in search of overarching twenty-first century book models and theories that can unify this complex landscape.

Murray's 2006 article is perhaps one of the most oft-cited critical accounts of late twentieth and twenty-first century book research. Murray proposed five key areas of research for the twentyfirst century book: "industry research and vocational information; personalized accounts such as memoirs, autobiographies, biographies and house histories; history of the book; communication, media, cultural studies and sociology; and nationalist and post-colonial studies." ${ }^{\text {"xxviii }}$ The first two nodes, industry research and vocational information and personalized accounts, Murray describes as being more anecdotal and descriptive, less critical, and typically written by members of the industry rather than academics. As this article focuses on more critically-engaged twentyfirst century book research, industry research and vocational information and personalized accounts are not useful research nodes for discussing twenty-first century book studies. Indeed, these two nodes exist within the publishing industry landscape, but do not offer the rigor necessary to the constitution of academic research. This does not mean that twenty-first century book research cannot be tied to the contemporary business environment -- indeed, it often is -but that a grounding in a theoretical basis and rigorous methodology are what differentiate twenty-first century book studies from these two nodes.

Additionally, Murray lists book history as a node of twenty-first century book research, rather than twenty-first century book research being an integral piece of the book history timeline. In this way, this article also disagrees with Murray, arguing that instead of book history being an 
area of twenty-first century book studies, that twenty-first century book studies is a particular period of book history. Established book history examples of research regarding the long twentyfirst century include the following: Alistair McCleery's An Honest Trade (2008) and Iain Stevenson's Bookmakers (2010) give histories of bookselling and publishing in the UK in the twentieth century. Likewise Jason Ensor's Angus \& Robertson and the British Trade in Australian Books, 1930-1970 (2013) and Beth Le Roux's A social history of the university presses in apartheid South Africa: Between complicity and resistance (2015) focus on the twentieth century in Australia and South Africa respectively.

Beyond book publications, there are several articles that address the twenty-first century book. David S. Miall's article on empirical studies of literary readers discusses the literary reading habits and reactions of twenty-first century university students. ${ }^{\text {xxix }}$ Trysh Travis's article on women in the print movement gives an account of late twentieth and early twenty-first century "bookwomen"xl and Susan Pickford's article on book prizes utilizes a corpus of book prize novels from 1969 to 2009 in order to compare how two different literary prizes traveled across national and linguistic bordersxli Finally, Alan Galey’s article “The Enkindling Reciter” (2012) uses a case study of the 2010 Canadian novel The Sentimentalists to illustrate how bibliography and textual scholarship is well-equipped to address the material nature of e-books. ${ }^{\text {xlii }}$

Communication, media, cultural studies and sociology is another key research node proposed by Murray. This was an area for twenty-first century book research that Murray called "a lost opportunity" because of the typical exclusion of books, despite it being the oldest form of media, from these disciplines. As Marsden has noted, such exclusion can go as far as being complete 
disregard of existing scholarship on the contemporary publishing industry. ${ }^{\text {xliii }}$ In "Positioning Publishing Studies in the Cultural Economy" Marsden recalls how the 2011 edited volume $A$ Handbook of Cultural Economies (which surveys the various economies of media forms such as radio, television, and film) asserted that there was a dismal dearth of research about the twentyfirst century book publishing industry:

The knowledge about publishing is very scattered and comes almost entirely from outside the academic world [...] The material relating to publishing is enormous, including official reports from various countries, memoirs, biographies and a large amount of anecdotal evidence, but solid knowledge based on research published in academic journals is scarce. ${ }^{\text {xliv }}$

Hjorth-Andersen's claim, however, is inaccurate because there are scholars conducting rigorous twenty-first century book studies research, but this claim does suggest that the "lost opportunity" of twenty-first century book research being situated within communication, media, and cultural studies is no more integrated or developed than when Murray was writing in 2006. One notable exception in the last decade has been Ted Striphas's The Late Age of Print (2009). Striphas's book offers a history of books as social artifacts from a mass communications lens, emphasizing the integral role of books in making the "modern, connected consumer." In essence, Striphas analyses the book as an artifact "through which social actors articulate and struggle over specific interests, values, practices, and worldviews." ${ }^{\text {xlv }}$

Nationalist and post-colonial studies is Murray's final research node. She notes that books are “key tools in decolonizing nations' struggles to achieve literary, educational and professional standards requisite for competitive, post-industrial economies." ${ }^{\text {"xlvi }}$. Recent contributions to this particular area of book history and publishing research include Sarah Brouillette's Postcolonial Writers and the Global Literary Marketplace (2007) which adds to the discussion of postcolonial 
studies and book history by scrutinizing the way that authors position themselves as postcolonial, in part as a marketing tool. ${ }^{\text {xlvii }}$ Robert Fraser's Book History Through Postcolonial Eyes: Rewriting the Script (2008) takes a more book historical approach to postcolonial literature, aiming to even the imbalance of book history's focus on Western histories of the book. Finally, in The Postcolonial Cultural Industry: Icons, Markets, Mythologies (2014) Sandra Ponzanesi notes how "the postcolonial agenda, as a field of resistance, rewriting and contestation of dominant and hegemonic forms of cultural appropriation and imposition, is still present."xlviii Ponzanesi considers postcolonial culture through a number of perspectives, including advertising and film adaptation, but spends much of the book analyzing postcolonial literature, particularly in relation to literary prizes, canon formation and the visibility of postcolonial authors in contemporary literary and publishing culture. Indeed, diversity and representation in literature, and the publishing industry more widely, are key areas currently being interrogated in twentyfirst century book scholarship. Notable contributions to debates surrounding representations of BAME (Black, Asian and Minority Ethnic) writers and publishers include Claire Chambers' 2010 article "Multi-Culti Nancy Mitfords and Halal Novelists: The Politics of Marketing Muslim Writers in the UK" "xlix , Corinne Fowler's 2013 piece "Publishing Manchester's black and Asian writers" from Postcolonial Manchester: Diaspora Space and the Devolution of Literary Culture ${ }^{1}$ and Squires' essay “Publishing's diversity deficit” (2017)

In addition to a post-colonial perspective, several twenty-first century book studies scholars also interrogate the role of the nation in book industries and processes by focusing research on the cultural and economic forces at play for national and regional literature and publishing industries. For example, Scottish national identity and the Scottish publishing industry in the 
long twenty-first century have been investigated by Alastair McCleery and Melanie Ramdarshan-Bold (2012) lii, $^{\mathrm{ii}}$ who discuss the transnational threats to linguistic and cultural diversity in the Scottish publishing industry; Claire Squires and Miha Kovač (2014) $)^{\text {liii }}$, who compare and contrast the Scottish and Slovenian book industries; Daniel Boswell (2014) $)^{\text {liv }}$, who compares the book industries in Catalan and Scotland; Rachel Noorda (2016) ${ }^{\mathrm{lv}}$, who investigates reading as a way for members of the Scottish diaspora to reinvent and reinterpret national symbols and myths; and Stevie Marsden (2016) ${ }^{\text {lvi }}$, who examines national identity and literature as intertwined in the history of a Scottish book award. Per Henningsgaard discusses regional literature in Western Australia ${ }^{\text {lvii }}$ and the contributors to Publishing Means Business: Australian Perspectives also offer insight into the publishing environment in Australia. ${ }^{\text {lvii }}$ Finally, scholars contributing to Hype: Bestsellers and Literary Culture discuss the particulars of the Swedish publishing industry. ${ }^{\text {lix }}$ Other studies, like Gillian Roberts' Prizing Literature: The Celebration and Circulation of National Culture (2011) ${ }^{\mathrm{lx}}$ and Edward Mack's Manufacturing Modern Japanese Literature: Publishing, Prizes and the Ascription of Literary Value (2010) ${ }^{\mathrm{lxi}}$, consider the propagation of ideals of national literatures and the literary values attributed to them via prize culture and canonization, in Canada and Japan respectively. More recently still, Marie Orton has written about national identity in Italian writing, with a particular consideration of migrant writers and how they 'interrogate the intertwined and mutually reinforcing assumptions that have traditionally shaped the idea of national literature'. lxii

However, despite this plethora of nationally-focused recent histories of the book, much like book history as a whole, transnational and global historical concerns are coming to the fore in twentyfirst century book studies. Sydney Shep has argued for a new type of book history that moves 
beyond a nationally-bound history of the book. ${ }^{\text {lxiii }}$ On the one hand, "the attempt to annex books to territories is--and always has been--an aspect of a wider programme of affiliation, identification and flag-waving ${ }^{\text {lxiv; }}$, however, on the other hand, books continue to become increasingly international in readership, impact, and history, particularly as we turn to recent history that includes decades following the rise of the internet.

It is worth noting that in addition to Murray's five nodes of research of the book in the long twenty-first century, Weber and Mannion in their chapter "Discipline and Publish" in Publishing Means Business assess the areas of research of the book in the long twenty-first century and offer their own nodes for describing this research. ${ }^{1 x v}$ The nodes they discuss are field mapping, sociological, technological, commercially and practically aware, politically and ethically aware, and interdisciplinary affordances. Murray's article is a good example of field mapping; indeed, Weber and Mannion assert that twenty-first century book research is exploratory in nature, and these authors cite Darnton's communications circuit as a first exploratory attempt to investigate what publishing is. "What We Write When We Write About Publishing"lxvi and "Positioning Publishing Studies within the Cultural Economy"|xvii are other examples of this mapping of the twenty-first century book history field. Weber and Mannion also argue that much twenty-first century book research is sociological in that "it is attuned to the ways in which print culture, and the creation, dissemination and reception of books, are socially constructed". Ixviii This aligns with Murray's node of communication, media, cultural studies and sociology. Additionally, Weber and Mannion identify "technological" as a node of twenty-first century book history, which "understands digital media as an object of study, and also uses new technology as a tool to help explore the ways in which publishing operates" (p. 190-191). This article addresses this 
"technological" node in the next section. The three nodes of commercially and practically aware, politically and ethically aware, and interdisciplinary affordances are features and considerations of book research of the long twenty-first century, rather than particular areas of emerging research. But all three reflect the closeness that twenty-first century book history research has with contemporary communities and with the industry.

In surveying the field in the 10 years since Murray's article was published, we propose three new nodes of long twenty-first century book studies research: digital (con)texts, economics of the book trade, and the cultural industry and economy.

\section{The Digital (Con)Text}

Digital texts, digital contexts, digital methods, and digital data can be found in most twenty-first century book research, making it impossible to address this area of study without discussing "the digital." In 2015, Murray noted how, despite the fact that the relationship between digital technologies and literary culture have been analyzed and critiqued since the early 1990s, critical engagement with this relationship often failed to fully understand the complexities of the impact digital technologies and literary culture had on each other. ${ }^{\text {Ixix }}$ According to Murray, much of the earliest discourse was repetitive, focusing on the supposed "death of the book" at the hand of technological advances and, by 2015 , there remained a "weary sense that, as a discipline, we

have been around this block before." ${ }^{\text {xx }}$ Bringing the existing information and data considering the digital and literary together, Murray proposes the term "the digital literary sphere" which, "encompasses the broad array of book-themed websites and other digital content whose focus is contemporary literature and its production". lxxi The inclusion of the word "literary" in this label 
is potentially problematic, since it has different connotations relating to other disciplines and methodological approaches and can also imply conceptions or judgments of value. ${ }^{\text {lxxii }}$ Accordingly, while Murray's term is a useful one that should remain part of the rhetoric of digital technologies and literary culture in the long twenty-first century, we favor a simplified and paired down terminology.

This node has purposefully been called "digital (con)texts" to differentiate it as an area of study focused on digital content, forms, and contexts as opposed to the use of digital methodologies. While twenty-first century book scholars commonly use digital methodologies - such as data scraping or mining, online surveys and computational analysis - these methodologies are not unique to research in the long twenty-first century. Many book historians (twenty-first century or otherwise) utilize digital tools and digital data in their research, an example being the Reader Experience Database, an online open access database which collects historic data related to reader experiences between 1450-1945. . $x x i i i$ While entirely digital in its configuration, this database is not dealing with texts which are digital in their original form. Likewise, Matthew L. Jockers' Macroanalysis: Digital Methods and Literary History (2013) explores how "massive digital-text collections" are "changing how literary studies gets done". Ixxiv While Jockers' focus in Macroanalysis is the use of digital methodologies in textual analyses of literature, and particularly historic materials, his survey of digital methods in the humanities is related to parallel developments within book history.

We propose that long twenty-first century research is in a unique position to use digital texts and contexts, such as websites, e-books, apps, social media, and audiobooks, to name but a few, in its 
analysis of contemporary book and publishing culture. But, identifying "digital (con)texts" as an individual node for long twenty-first century book research is not to suggest that the digital does not intermingle with the other nodes discussed in this article. In other words, other areas of long twenty-first century book research put forth by Murray and by the authors of this article are rarely, if ever, entirely "digital-free."

It is assumed that in the long twenty-first century almost every traditionally published book will also, and often simultaneously, have a digitally published counterpart (commonly an ebook, but in some circumstances apps, games and online-only content has been released in conjunction with publications) and sometimes a publisher or self-published author will decide to forego the print book altogether and publish digitally-only. Yet, in the aftermath of the predicted demise of the print book, there has been a swing back to the defending of the traditional codex against the digital, often leading to an overemphasis on the virtues of the print book and a minimizing of the history and value of digital forms. Miha Kovač's Never Mind the Web: Here Comes the Book (2008) and Naomi Baron's Words Onscreen (2015) both present research and arguments that position print and digital as rivals rather than necessarily interconnected. While book historians would agree that the printed codex is alive and well, research and arguments that juxtapose print and digital in this way risk misrepresenting digital (con)texts. This is similar to the outcries of the "death of the book" (meaning the death of the print codex) and arguments which have been reductive and uninformed at best. Sarah Werner and Matt Kirschenbaum, in their thorough overview of the state of the discipline of digital scholarship, acknowledge that in many ways, a book history perspective is the best method for bringing "much-needed nuance to tired, reductive binaries around the paragone between print and digital." ${ }^{\prime \times x v}$ In an effort to intentionally distance 
this discussion from the print vs. digital dichotomy, it is useful to bring to the fore the theme of materiality that has emerged in long twenty-first century book literature in the area of digital (con)texts.

The materiality of digital texts might at first seem paradoxical. However, Kirschenbaum and Werner note that the decade-long "material" turn in studies of the digital mirrors a similar turn to materiality in book history more widely. Matt Kirschenbaum's Mechanisms (2008) argues that electronic writing must be understood as a "real", or material, form of writing, thus emphasizing the materiality of both the process and the product of electronic writing. His use of concepts and theory from forensic science offer a new way to think about electronic writing as a series of material events that never go away. ${ }^{\text {lxvi }}$ In Mechanisms Kirschenbaum demonstrates that focusing on the materiality of digital texts can fruitfully move the discussion from a print vs digital dichotomy. Kirschenbaum and Werner also argue that understandings of the materiality of the digital benefit from a specific branch of media studies known as "platform studies" which is, according to Kirschenbaum and Werner, "like the history of the book" in that it is,

[C]haracterized by close [...] attention to detail out of the fundamental conviction that such material particulars are ineluctably part of the history of communicative objects [...] and our human interaction with them. ${ }^{\text {lxxvii }}$

This interdisciplinary approach is also favoured by Simon Rowberry in his analysis of ebook design over time (Rowberry, 2017). ${ }^{\text {lxxiii }}$ Other areas in the study of digital texts include the history of digital texts ${ }^{\text {lxxix }}$ and media archaeology ${ }^{\text {lxxx}}$; however, these areas of digital scholarship are less focused on the long twenty-first century and therefore less relevant to our discussion about twenty-first century book studies scholarship. 
One of the differentiating features of book history (particularly in contrast to literary/textual studies) is its focus not on the text itself, but the context in which those texts are produced and consumed. This is equally apparent in the study of digital texts in the long twenty-first century, where digital composition and reception are integral to the current body of research. For example, Kirschenbaum's Track Changes maps the relationship between authorship and computer processing in its social, cultural, and economic contexts (2016). ${ }^{\text {lxxi }}$ Other scholars have studied the contexts of electronic literature, such as Kathi Berens's research on the reception of work by hypertext pioneer Judy Malloy. ${ }^{\text {lxxxii }}$ Thus, the materiality, composition, and reception of digital (con)texts is central to a discussion of the "digital" when it comes to the long twenty-first century.

In summation, this article's definition of digital (con)texts envelops the digital content and context, including the materiality of the digital, with an understanding that a majority of this research is focused on the long twenty-first century. Murray has noted that what is currently missing from academic interrogations of twenty-first century book culture are "digital literary studies that [are] both contemporary and contextual"lxxxii , but this research is emerging and will continue to grow in the coming years ${ }^{\text {lxxiv }}$. Digital (con)texts have not only inspired new avenues of research, but they also facilitate research that is decidedly twenty-first century whilst remaining part of the wider history of the book. As Werner and Kirschenbaum argue, "If book history is the study of how platforms shape and deliver texts, then today's platforms of pixels and plastic are as much a part of those studies as paper and papyrus."'xxxv

\section{Economics of the Book Trade}


One of Murray's nodes, "industry research and vocational information", is described as the “earliest genre of publishing commentary." (Murray 2006: 5) This is where late twentieth and twenty-first century research had its beginnings: in musings on the dynamics of the book trade from successful leaders in the industry that eventually led to career guides and introductory textbooks for publishing courses. ${ }^{\text {lxxxvi }}$ In the last decade, this type of research has continued in

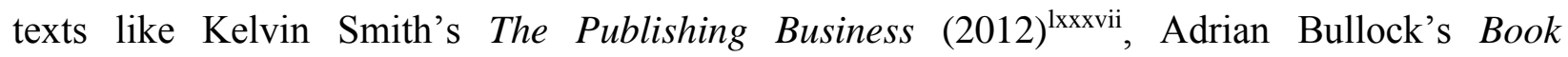

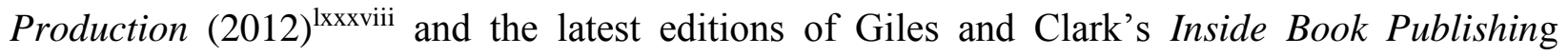
$(2014)^{\text {lxxxix }}$, Alison Baverstock's How to Market Books (2015) ${ }^{\mathrm{xc}}$, Lynette Owen's Selling Rights $(2014)^{\mathrm{xci}}$, and others. Rightly so, Murray criticizes this type of research because of its "reliance on descriptive rather than critical modes of analysis."xcii However, not all business-related twenty-first century book research would fall into this descriptive "industry research and vocational information" category.

Research on the economics of the book trade address several sub-areas: consumer behavior of readers (Brown, 2006) $)^{\text {xciii }}$, marketing (Squires, 2007 ${ }^{\text {xciv }}$; Matthews and Moody, 2007 ${ }^{\mathrm{xcv}}$ ), branding $^{\mathrm{xcvi}}$, and management models ${ }^{\mathrm{xcvii}}$, to name some of the most prominent. Typically the approach to the economics of the book trade is qualitative or mixed method rather than relying on the quantitative methods that dominate business research more generally, which is unsurprising considering that the publishing industry itself is an intersection between business, literature and culture. Additionally, many long twenty-first century book researchers, even those researching within the economics of the book trade, are often positioned within departments in the humanities and come from humanities backgrounds, and their methodological approaches often reflect this background and positioning. The dominance of a qualitative humanities-centric 
background and approach from long twenty-first century book scholars illustrates a gap and need for increased collaboration with researchers from the sciences. While there are hurdles in working with quantitative data, such as that offered by Nielsen BookScan (although this data provider captures and presents book sales data, it does not offer a complete picture of sales and is expensive to access), a richer understanding of the economics of the twenty-first century book trade necessitates more variety in terms of methods and interdisciplinary collaboration.

However, there are researchers who come from the social sciences, in this case from business schools, and conduct research on the more humanities-focused (or at least humanitiessympathetic) twenty-first century book. Stephen Brown, who is a marketing and consumer behaviour researcher positioned in a business and management research institute, is one such researcher. Brown is the editor of Consuming Books: The Marketing and Consumption of Literature (2006), which is a compilation of research that rather than addressing the particulars of marketing, focuses on a broader consumer research/consumer behavior macro-analysis of the book trade, focusing primarily on the long twenty-first century. The volume explores trends in consumption behavior, such as meet-the-author culture, readers as consumer-producers, and the sociality of reading as evidenced in book clubs. While the sociality of reading has been explored by other scholars (most notably by Danielle Fuller and DeNel Rehberg-Sedo ${ }^{\text {xcviii }}$ and Beth Driscoll $\left.^{\text {xix }}\right)$, Consuming Books's consumer behavior perspective not only engages with the relevant scholarship of business schools but also offers book history valuable theoretical insights, such as the concept of "subcultures of consumption," a useful framework for considering the sociality of reading. Indeed, this integration of concepts and theory from business sub-disciplines 
(such as consumer behavior and marketing) is one of the great strengths and contributions of this area of long twenty-first century book history research as a whole.

In the sub-area of marketing, Claire Squires' Marketing Literature (2007) similarly offers a critical, business-oriented perspective to late twentieth and early twenty-first century book history. Squires investigates the representation and interpretation of texts in the marketplace through case studies of a series of high-profile books and interviews with members of the publishing industry in Britain. Through this investigation Squires studies the complex, manifold ways in which the appeal for a book is constructed. Likewise, Matthews and Moody's edited volume Judging a Book by Its Cover (2006) addresses the positioning of books in the marketplace. Royle and Laing (2006) apply branding theory to the book industry in the long twenty-first century in their analysis of branding efforts for UK bookshops Marianne Martens's Publishers, Readers, and Digital Engagement (2016) which explores the consumer behavior of online reading communities on RandomBuzzers, TwilightSaga.com, and The Amanda Project. Simon Frost addresses how the business model and management of British book retailer John Smith's in the long twenty-first century involves the power dynamics between various "actors" in the communications circuit in a reading that is "commercially mediated" and based on a “conception of gains" (Frost, 2015). Business management scholar Susanne Bartscher-Finzer uses quantitative statistical analysis of survey data to assess the effect of motivations of book publishers on their entrepreneurial orientations. ${ }^{\text {ci }}$ Additionally, well-known cultural economist David Throsby have examined book publishing from an economics perspective, such as in his research concerning the balance between culture and commerce in the Australian Book 
Industry. ${ }^{\text {cii }}$ Finally, Ann Steiner analyzes the marketing and consumption of bestsellers in Europe and North America from 2004-2013. ${ }^{\text {ciii }}$

It is worth noting that because the economics of the book trade are so interconnected with more literary and cultural aspects of the industry, many long twenty-first century book scholars incorporate elements of the economics of the book trade into their research, even if this area is not the exclusive or primary focus of the research. One recent example is in Jeremy Rosen's Minor Characters Have Their Day: Genre and the Contemporary Literary Marketplace (2016). Although his research is focused primarily on genre study and mapping the history of minorcharacter elaboration as a genre, Rosen also analyzes the marketing of texts within this genre in order to study the commercial economy in which the genre operates. However, this section, and this proposed node for current and future research regarding book studies in the long twenty-first century, have addressed research that is primarily concerned with the economics of the book trade and in incorporating economic and business theory into frameworks and methodologies.

\section{The Cultural Industry and Economy}

This node considers, and reframes, twenty-first century book study in relation to the cultural economy and related industries. The authors of this article posit that publishing and related facets of book culture (such as festivals, prizes, multi-media adaptations) should be considered as key elements of the cultural industry and economy. ${ }^{\text {civ }}$ In The Cultural Industries (2013), David Hesmondhalgh writes that the 'cultural industries are concerned, fundamentally, with the 
management and selling of a particular kind of work' ${ }^{\mathrm{cv}}$ Hesmondhalgh continues, explaining how:

[T]he cultural industries have usually been thought of as those institutions (mainly profit-making companies, but also state organisations and non-profit organisations) that are most directly involved in the production of social meaning. Therefore, nearly all definitions of the cultural industries would include television [...] radio, the cinema, newspaper, magazine and book publishing, the music recording and publishing industries, advertising and the performing arts. ${ }^{\text {cvi }}$

Such definitions are useful to consider in relation to twenty-first book research because they encourage multilateral examinations of the book and how it functions in contemporary culture in relation to other cultural products.

In recent years there has been a surge in critical discourse surrounding the cultural value and economies of publishing and literature and such works have become central to the development of twenty-first century book studies. James F. English's The Economy of Prestige: Prizes, Awards and the Circulation of Cultural Value (2008) has become a leading text in the development of understandings of some of the key agents working within contemporary book marketing. Through an exploration of the development of cultural prizes over time, and how Pierre Bourdieu's forms of capital are negotiated and "intraconverted" through the various processes of prize giving, in The Economy of Prestige, English proffers insights and approaches to looking at how these particular agents function within the book market and the wider implications these have on the literary economy. Similar works concerned with contemporary publishing and literary culture, and how agents within the publishing industry function as tastemakers and curators of cultural value, include Jim Collins' Bring on the Books for 
Everybody: How Literary Culture Became Popular Culture (2010), Edward Mack's Manufacturing Modern Japanese Literature: Publishing, Prizes and the Ascription of Literary Value (2010), Beth Driscoll's The New Literary Middlebrow: Tastemakers and Reading in the Twenty-First Century (2014) and Archer and Jocker's The Bestseller Code: Anatomy of the Blockbuster Novel (2016). While elements of these works are specific in subject matter, and could potentially be viewed as sub-disciplines of twenty-first century book research, they nonetheless contribute to broadening the field of the discipline through their analyses of contemporary literary culture, economy and marketplace.

Other works, such as Fuller and Rehberg-Sedo's Reading Beyond the Book: The Social Practices of Contemporary Literary Culture (2013) explore such themes in terms of socialities and behaviours of reading. But the key difference in Fuller and Rehberg-Sedo's work, as well as that of Simone Murray's The Adaptation Industry: The Cultural Economy of Contemporary Literary Adaptation (2011), is that in these texts the publishing industry is not only considered in relation to cultural values, but also in relation to the wider cultural economy and related industries. Both Fuller and Rehberg-Sedo, and Murray consider the production, marketing and reading of books in relation to other media such as radio, television and film. This is an important development within long twenty-first century studies of the book because it not only allows for comparative analyses of the production and circulation of different types of media and text, but it also opens the door for considering the contemporary publishing industry in terms of academic discourses and critical frameworks used by scholars studying different cultural industries. 
Sarah Brouillette eloquently testifies to the long-running connections between publishing and literature, and the cultural economy more widely, in Literature and the Creative Economy (2014). Brouillette notes how one of the key foci of the book is 'how literature has reflexively exemplified, internalized, and critiqued vocabularies and phenomena that are integral to our unfolding creative-economy era'.$^{\text {cvii }}$ Contextualising her analysis within the UK New Labour government's political cultural policies of the late 1990s and early 2000s, which purported to make culture 'central to negotiating the symbioses between economic and social goals, ${ }^{\text {cviii }}$ Brouillette considers the role and status of the writer as creative worker, both in literature (through analyses of Aravind Adiga's The White Tiger (2008), Monica Ali's In The Kitchen (2009), Daljit Nagra's Look We Have Coming to Dover! (2007) and Gautum Malkani's Londonstani (2006)), and in real life (through analyses of cultural policies and the actions of cultural policymakers). Brouillette's work is significant in relation to thinking about the future of long twenty-first century studies of the book because it broadens the scope of how we think about the politicization of the book in contemporary society.

Indeed, when considering future directions for twenty-first century book studies in 2006, Murray argued that this area "must engage with mainstream humanities debates by entering into critical dialogue with contemporary cultural theory" cix , but warned that "unless researchers of contemporary book publishing consciously work to dismantle [inherited] disciplinary divides, important theoretical innovations in one field will fail productively to inform the other" ${ }^{\mathrm{cx}}$. Over the past ten years there have been developments in cultural studies scholarship which may prove invaluable to studies of contemporary book publishing and its role within the cultural economy. Specifically, in the last decade there has been an upsurge in critical discourses surrounding the 
dynamics and politics of creative labour. These include Mark Banks' The Politics of Cultural Work (2007), which takes a sociological approach to examining theories of cultural work and the position of the cultural worker today. David Hesmondhalgh and Sarah Baker's Creative Labour (2011), which uses empirical data collected from the study of three cultural industries television, music recording and magazine publishing - to examine understandings of creative work. Likewise, Theorizing Cultural Work (2013) edited by Banks, Gill and Taylor, which includes essays considering creative work and identity, copyright, representation and participation. We highlight this particular area of cultural studies because it so clearly aligns with some of the research foci of long twenty-first century book studies, particularly in terms of the disciplines' vocational background and interest in industry experience. Furthermore, this cultural studies framework of considering the nuances of creative/cultural work, and workers, presents long twenty-first century book scholars with a framework by which to consider the socio-political contexts of book production (from writer, to agent, to editor) today.

\section{The Future of Long Twenty-First Century Book Research}

These three research areas within long twenty-first century book studies - digital (con)texts, economics of the book, and the cultural industry and economy - are branches where we anticipate research of the long twenty-first century book will continue to grow in the coming years. Moving beyond the digital vs. print dichotomy will enable long twenty-first century book historians to examine more fully the processes, forms, and content of digital (con)texts, particularly if this examination can inform, and be informed by, a longitudinal perspective of the book and its history. Scholarship continues to emerge at the intersections between economics, 
literature and culture, but there is a need for even more coalescing between economics and long twenty-first century book history, particularly given that the book publishing industry is subject to economic conditions and concerned with economic value. Additionally, positioning the twenty-first century book within the creative and cultural economy can create fruitful crosspollination between twenty-first century book history and research regarding other media industries, while also engaging with industry.

As a period of book history research, long twenty-first century book studies benefits from the interdisciplinary nature of book history, although this article calls for a deeper interdisciplinarity rather than the haphazard interdisciplinarity that book history research runs the risk of employing. Unlike the nebulous term "publishing studies", long twenty-first century books studies is not, and need not be, uncritical or lacking in theoretical base. One of the great advantages of book history research is that studying the book intersects with the theoretical frameworks from many other disciplines, including media/cultural studies, sociology, and economics. Methods aligned with other recent history approaches, such as oral testimony and new media related methods, afford researchers of the twenty-first century book the ability to study the history of the book as it is unfolding.

The purpose of this article has been three-fold: to respond to and update Simone Murray's 2006 article in light of the research in this area that has been published in the proceeding decade, to map the development of twenty-first century book research over the last 10 years by providing a literature review, and to offer additional research "nodes" to complement and expand the nodes provided by Murray. While this overview of the current state of the discipline of twenty-first 
century book studies aims to consider the subject in the widest possible terms, and collate the relevant existing literature, it is not, and we believe cannot ever truly be, an exhaustive list. Rather the aim of this article is to pinpoint key research that has shaped this area of book history thus far, and to contribute to the ongoing conversation of the status and discipline of the twentyfirst century book. It is likely other scholars working within this field identify further 'nodes' which contribute to our understanding of this contemporary research, and we invite complementary contributions to this conversation.

\footnotetext{
${ }^{\text {i }}$ Simone Murray, "Publishing Studies: Critically Mapping Research in Search of a Discipline," Publishing Research Quarterly, 22, no. 4 (2006): 3-25.

ii Sophie Noel, "Publishing studies: the search for an elusive academic object" Libellarium, VIII, 1 (2015): 139-145.

iii Michael Bhaskar, The Content Machine: Towards a theory of publishing from the printing press to the digital network, (London: Anthem Press, 2013), 4.

iv Boswell, Daniel. "What We Write About When We Write About Publishing," Interscript, March 13, 2017. https://www.interscriptjournal.com/online-magazine/what-we-write-about-when-we-write-about-publishing.

"Noël, "Publishing studies," 140.

${ }^{\mathrm{vi}}$ As evidenced by PhD programs and research in publishing studies in the UK (University of Stirling, Edinburgh Napier University, Oxford Brookes University, University College London, and King's College London); in the US, for example, there are no designated $\mathrm{PhD}$ programs in publishing studies. Additionally, the principal works defining and utilizing the term publishing studies, (including Murray, "Publishing Studies," 2006) often come from researchers in these two countries.

vii Noël, "Publishing studies," 140.

viii Millicent Weber \& Aaron Mannion, 'Discipline and Publish: Disciplinary Boundaries in Publishing Studies', in Publishing Means Business: Australian Perspectives, (Melbourne: Monash University Publishing, 2017)

ix Robert Darnton, "What Is the History of Books?," Daedalus, 1982, 65.

${ }^{x}$ Per Henningsgaard, "Emerging from the Rubble of Postcolonial Studies: Book History and Australian Literary Studies," Ilha Do Desterro 69, no. 2 (2016): 121.

xi “Overview," Book History Journal, accessed May 21, 2018, https://www.press.jhu.edu/journals/book-history.

xii Renee C. Romano and Claire Bond Potter, "Just over Our Shoulder: The Pleasures and Perils of Writing the Recent Past," in Doing Recent History : On Privacy, Copyright, Video Games, Institutional Review Boards, Activist Scholarship, and History That Talks Back, ed. Renee C. Romano and Claire Bond Potter (Athens: University of Georgia Press, 2012), 3.

xiii Gary Osmond, "Tweet out? Twitter, Archived Data, and the Social Memory of out LGBT Athletes," Journal of Sport History 44, no. 2 (2017), 326.

${ }^{\text {xiv }}$ Axel Bruns and Katrin Weller, "Twitter as a First Draft of the Present: And the Challenges of Preserving It for the Future," in Proceedings of the 8th ACM Conference on Web Science (8th ACM Conference on Web Science, Hannover, Germany, 2016), 183.

${ }^{\mathrm{xv}}$ For use of oral testimonies, see: John B. Thompson, Merchants of Culture: The Publishing Business in the Twenty-First Century (John Wiley \& Sons, 2013); Miha Kovač and Claire Squires, "Scotland and Slovenia," Logos 25, no. 4 (2014): 7-19, https://doi.org/10.1163/1878-4712-11112054; Rachel Noorda, "The Power of the Small Press: Entrepreneurial Publishing and Disruption of the Industry.," TXT, no. 1 (2016): 87-93; and for use of new media sources see: Lisa Nakamura, “'Words with Friends': Socially Networked Reading on Goodreads," PMLA 128, no. 1 (2013): 238-243, https://doi.org/10.1632/pmla.2013.128.1.238; Melanie Ramdarshan Bold, "The Return of the Social Author Negotiating Authority and Influence on Wattpad," Convergence 24, no. 2 (2016): 117-36,
} 
https://doi.org/10.1177/1354856516654459; Miriam J. Johnson, "The Rise of the Citizen Author: Writing Within Social Media," Publishing Research Quarterly 33, no. 2 (2017): 131-46; Nick Canty and Jamie Criswell, "Deconstructing Social Media: An Analysis of Twitter and Facebook Use in the Publishing Industry," Publishing Research Quarterly 30, no. 4 (2014): 352-76, https://doi.org/10.1007/s12109-014-9376-1.

${ }^{\text {xvi }}$ Padmini Ray Murray and Claire Squires, "The digital publishing communications circuit," Book 2.0 3, no. 1 (2013): 3-23.

xvii Roger Chartier, Forms and meanings: Texts, performances, and audiences from codex to computer.

(Pennsylvania: University of Pennsylvania Press, 1995), 20.

xviii Eva Mroczek, "Thinking Digitally About the Dead Sea Scrolls: Book History Before and Beyond the Book." Book History 14, no. 1 (2011): 241-269.

xix John B. Thompson, Merchants of culture: the publishing business in the twenty-first century, (John Wiley \& Sons, 2013), p. 41.

${ }^{x x}$ Marianne Martens, Publishers, Readers, and Digital Engagement (Palgrave Macmillan, 2016).

${ }^{x x i}$ Alistair McCleery, David Finkelstein \& Jennie Renton, An Honest Trade: Booksellers and Bookselling in Scotland, (Edinburgh: John Donald Publishers Ltd, 2009), xx.

xxii Stephen Brown, ed., Consuming Books: The Marketing and Consumption of Literature, (Oxford: Routledge, 2006).

xxiii Simon Rowberry, 'Ebookness', Convergence 23, no. 3 (2017): 289-305.

xxiv Simone Murray, "Publishing Studies: Critically Mapping Research in Search of a Discipline," Publishing

Research Quarterly, 22, no. 4 (2006): 3-25.

xxv John Tebbel, "Education for Publishing," Library Trends, Fall 1984, 223-33; Alexander J. Burke, Jr., "College of the Book: Teaching Publishing Studies to Undergraduates," Logos 17, no. 2 (2006); Miha Kovač, "The Issue of Publishing Education," Logos, no. 3 (2008); Fytton Rowland, "Degree Courses in Publishing at British

Universities," Serials 13, no. 3 (2003): 167-73, https://doi.org/10.1629/13167.

xxvi John Maxwell has written about the creation, purpose and vision of the program at Simon Fraser University in Vancouver, Canada, established in the 1990s, see: John W. Maxwell, "Publishing Education in the 21st Century and the Role of the University," Journal of Electronic Publishing 17, no. 2 (2014).

xxvii In Publishing Means Business: Australian Perspectives, Millie Weber and Aaron Mannion, assert that the first graduate diploma in publishing in Australia was offered by RMIT in 1988. Weber \& Mannion, "Discipline and Publish," 2017.

xxviii In a paper presented at 'By the Book Conference' in May 2015, Lucy A. Ry-Kottoh ( instructor on the publishing program at Kwame Nkrumah University of Science and Technology with a PhD in publishing studies at the University of Stirling) noted the development of the KNUT publishing program in the 1980s, followed by programs in Ghana, Nigeria, Kenya and South Africa. Lucy Ry-Kottoh, "Publishing Studies as an Academic Discipline or Professional Programme: An African Perspective" (By the Book Conference, Florence, Italy, 2015). xxix The publishing program at the University of Pretoria was established in 1997. "History," University of Pretoria, 2017, http://www.up.ac.za/en/information-science/article/47918/history.

${ }^{\mathrm{xxx}}$ Alexander J. Burke, Jr., "College of the Book: Teaching Publishing Studies to Undergraduates," Logos 17, no. 2 (2006): 96.

xxxi Murray, "Publishing Studies," 3.

xxxii Miha Kovač, "Reading the texts on book publishing: a new body of knowledge about an old body of

knowledge," Publishing Research Quarterly, 23, no. 4 (2007): 241-253.

xxxiii Kovač, "Reading the texts," 248.

xxxiv Kovač, "Reading the texts," 249.

${ }^{x x x v}$ Squires and Ray Murray, "The digital publishing communications circuit."

xxxvi Robert Darnton, "What is the History of Books?" Daedalus (1982): 65-83.

xxxvii For more on the selection and curation concepts introduced in the "filtering" portion of the model in The

Content Machine, see Bhaskar's Curation: The Power of Selection in a World of Excess (London: Piatkus, 2016). xxxviii Murray, "Publishing Studies," 4.

xxxix David S. Miall, "Empirical approaches to studying literary readers: The state of the discipline," Book History 9 , no. 1 (2006): 291-311.

${ }^{x l}$ Trysh Travis, "The women in print movement: History and implications," Book History 11, no. 1 (2008): 275-300. xli Susan Pickford, "The Booker Prize and the Prix-Goncourt: a case study of award-winning novels in translation," Book History 14, no. 1 (2011): 221-240. 
xlii Alan Galey, "The Enkindling Reciter: E-books in the bibliographical imagination," Book History 15, no. 1 (2012): 210-247.

xliii Stevie Marsden, "Positioning Publishing Studies in the Cultural Economy." Interscript, June 13, 2017, https://www.interscriptjournal.com/online-magazine/positioning-publishing-studies-in-the-cultural-economy. xliv Christian Hjorth-Andersen, "Publishing." in A Handbook of Cultural Economics, ed. Ruth Towse, (Cheltenham: Edward Elgar, 2011), 399.

${ }^{x l v}$ Ted Striphas, The Late Age of Print: Everyday book culture from consumerism to control, (Columbia University Press, 2009), 3.

xlvi Murray "Publishing Studies," 14.

xlvii Sarah Brouillette, Postcolonial Writers and the Global Literary Marketplace, (London: Palgrave Macmillan, 2007).

xlviii Sandra Ponzanesi, The Postcolonial Cultural Industry: Icons, Markets, Mythologies, (London: Palgrave Macmillan, 2014): 1.

xlix Claire Chambers, "Multi-Culti Nancy Mitfords and Halal Novelists: The Politics of Marketing”, Textus 23, no. 2 (2010): 389-403.

${ }^{1}$ Corinne Fowler, "Publishing Manchester's black and Asian writers," in Postcolonial Manchester: diaspora space and the devolution of literary culture, ed. by Robert H Crawshaw, Corinne Fowler and Lynne Pearce (Manchester: Manchester University Press, 2013), 79-110.

li Claire Squires, "Publishing's Diversity Deficit", CAMEo Cuts No.2, (Leicester: CAMEo Research Institute for Cultural and Media Economies, University of Leicester, 2017).

lii Alistair McCleery and Melanie Ramdarshan Bold, "What Is My Country?: Supporting Small Nation Publishing," Journal of Irish and Scottish Studies 6, no. 1 (2012): 115-31.

liii Kovač and Squires, "Scotland and Slovenia."

${ }^{\text {liv }}$ Daniel Boswell

lv Noorda, "The Power of the Small Press."

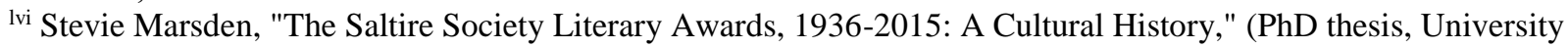
of Stirling, 2016).

lvii Per Henningsgaard, "Outside Traditional Book Publishing Centres: The Production of a Regional Literature in Western Australia” (PhD Thesis, University of Western Australia, 2008).

lviii Millicent Weber, Aaron Mannion, and Katherine Day, eds., Publishing Means Business: Australian Perspectives (Melbourne: Monash University Publishing, 2017).

lix Helgason, Jon, Sara Kärrholm, and Ann Steiner, eds. Hype: Bestsellers and Literary Culture. Nordic Academic Press, 2014.

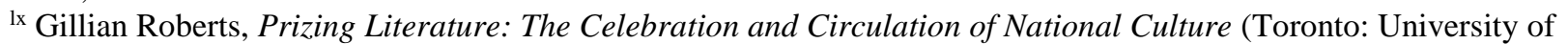
Toronto Press, 2011).

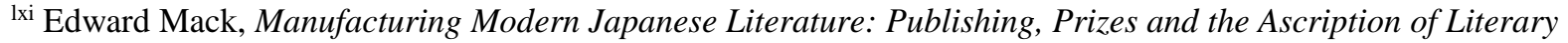
Value, (Duke University Press, 2010).

lxii Marie Orton, "Writing the Nation: Migration Literature and National Identity", Italian Culture 3:1 (2012): 21.

lxiii Sydney Shep, "Books Without Borders: The Transnational Turn in Book History," in Books Without Borders, ed. Robert Fraser and Mary Hammond, vol. 1 (London: Palgrave Macmillan, 2008).

lxiv Robert Fraser and Mary Hammond, "Introduction," Books without Borders, 1-12.

lxv Weber \& Mannion, "Discipline and Publish," 2017.

lxvi Boswell, "What We Write About When We Write About Publishing," 2017.

lxvii Marsden, "Positioning," 2017.

lxviii Weber \& Mannion, "Discipline and Publish,"188.

lxix Simone Murray, "Charting the Digital Literary Sphere”, Contemporary Literature 56, no. 2 (2015): 312.

1xx Murray, "Charting the Digital Literary Sphere," 312.

lxxi Murray, "Charting the Digital Literary Sphere," 313.

lxxii Claire Squires, Marketing Literature: The Making of Contemporary Writing in Britain, (London: Palgrave Macmillan, 2007), 4.

lxxiii “The Reading Experience Database (RED), 1450-1945)", The Open University, accessed August 7, 2017, http://www.open.ac.uk/Arts/RED/

lxxiv Matthew L. Jockers, Macroanalysis: Digital Methods and Literary History. (Urbana: University of Illinois Press, 2013), 7. 
${ }^{1 x x v}$ Matthew Kirschenbaum and Sarah Werner, "Digital scholarship and digital studies: the state of the discipline," Book History 17, no. 1 (2014), 440.

lxxvi Matthew Kirschenbaum, Mechanisms: New media and the forensic imagination, (Cambridge: MIT Press, 2008).

Ixxvii Kirschenbaum and Werner, "Digital scholarship," 434.

lxxviii Rowberry, "Ebookness", 2017.

${ }^{\text {Ixxix }}$ For example, Matt Rubery explores the 150-year-old history of audiobooks, beginning in 1877 with Edison's reciting on a phonograph. Matt Rubery, The Untold History of the Talking Book (Cambridge: Harvard University Press, 2016).

Ixxx Exemplified by Lisa Gitelman's Paper Knowledge (2014), which gives a history of the vernacular genre of documents that extends from the 19th century to the present day. Lisa Gitelman, Paper Knowledge: Toward a Media History of Documents, (Durham: Duke University Press, 2014).

Ixxxi Matthew G. Kirschenbaum, Track Changes: A Literary History of Word Processing, (Cambridge: Harvard University Press, 2016).

lxxxii Kathi Berens, "Judy Malloy's seat at the (database) table: a feminist reception history of early hypertext literature," Literary and Linguistic Computing 29, issue 3 (2014): 340-348.

Ixxxiii Murray, "Charting the Digital Literary Sphere," p. 319.

Ixxxiv At the 2017 SHARP conference there were a number of research papers which used multi-method approaches to the contemporary and contextual analyses of digital texts, for example, Laura Blair, "Reading and Reviewing in the Digital Era: Examining Readers and Reader Response Using Goodreads.com"; Maxine Branagh-Miscampbell and Stevie Marsden, “"'The Commodification of the Ideal Young Female Reader in the 21st Century: Zoella Book Club, A Case Study", Beth Driscoll and Claire Squires, "Serious Fun: Gaming the Book Festival," and Simon Rowberry, “"'Modelling the Book: Amazon's Patents and the Book as Technology”. Other examples include Melanie Ramdarshan-Bold's "The Return of the Social Author," 2016; Miriam Johnson's, "The Rise of the Citizen Author," 2017; and Millicent Weber, "Conceptualizing Audience Experience at the Literary Festival", Continuum: Journal of Media and Cultural Studies, 29 no.1 (2015): 84-96.

Ixxxv Kirschenbaum and Werner, "Digital scholarship," 451.

Ixxxvi See Stanley Unwin, The Truth About Publishing (1926); John Baker, The Book Business (1971); Elizabeth A. Geiser, Arnold Dolin and Gladys S. Topkis, eds, The Business of Book Publishing: Papers by Practitioners (1985); Peter Owen, ed., Publishing - The Future (1988); John P. Dessauer, Book Publishing: A Basic Introduction, $3^{\text {rd }}$ edition (1989); Peter Owen, ed, Publishing Now (1993); Gordon Graham, As I Was Saying: Essays on the International Book Business (1994); Alison Aprhys, Careers in Publishing and Bookselling: How to Get the Job You Want (1997); Murray, "Publishing Studies," 5.

lxxxvii Kelvin Smith, The Publishing Business: From p-Books to e-Books (London: AVA Publishing, 2012).

lxxxviii Adrian Bullock, Book Production (Abingdon: Taylor \& Francis Ltd, 2012).

Ixxix Giles Clark and Angus Phillips, Inside Book Publishing, 5th ed. (Abingdon: Routledge, 2014).

${ }^{x c}$ Alison Baverstock, How to Market Books, 5th ed. (Abingdon: Routledge, 2015).

${ }^{x c i}$ Lynette Owen, Selling Rights, 7th ed. (Abingdon: Routledge, 2014).

xcii Murray, "Publishing Studies," 6.

xciii Stephen Brown, Consuming Books: The Marketing and Consumption of Literature (Oxford: Routledge, 2006).

xciv Squires, Marketing Literature, 2007.

${ }^{x c v}$ Nickianne Moody and Nicole Matthews, eds., Judging a Book by Its Cover: Fans, Publishers, Designers, and the Marketing of Fiction (Hampshire: Ashgate Publishing, Ltd, 2007).

xcvi Audrey Laing and Jo Royle. "Marketing and the bookselling brand: Current strategy and the managers' perspective," International Journal of Retail \& Distribution Management 34, no. 3 (2006): 198-211.

xcvii Simon Frost. "Bespoke bookselling for the twenty-first century: John Smith's and current UK higher education." Book 2.0 5, no. 1-2 (2015), 39-57.

xcviii Danielle Fuller and DeNel Rehberg Sedo, "Fun...And Other Reasons for Sharing Reading With Strangers:

Mass Reading Events and the Possibilities of Pleasure," in McKechnie, Lynne (E.F.), Knut Oterholm, Paulette M. Rothbauer and Kjell Ivar Skjerdingstad, eds. Plotting the Reading Experience: Theory/Practice/Politics. (Waterloo: Wilfrid Laurier University Press, 2016): 133-147.

xcix Beth Driscoll, "Readers of Popular Fiction and Emotion Online," in New Directions in Popular Fiction: Genre, Distribution, Reproduction, ed. Ken Gelder (London: Palgrave Macmillan, 2016): 425-449. 
${ }^{\mathrm{c}}$ First introduced by John W. Schouten and James H. McAlexander, "Subcultures of consumption: An ethnography of the new bikers." Journal of consumer research 22, no. 1 (1995): 43-61.

${ }^{c i}$ Susanne Bartscher-Finzer, "Proactivity and the Entrepreneurial Self-Concept of Book Publishers" in Publishing Means Business (2017), 48.

cii David Throsby, "Commerce or culture? Australian book industry policy in the twenty-first century" in Publishing Means Business (2017), 1-21.

ciii Ann Steiner, "Serendipity, Promotion, and Literature: The Contemporary Book Trade and International Megasellers," in Hype: Bestsellers and Literary Culture, ed. Jon Helgason, Sara Kärrholm, and Ann Steiner (Lund: Nordic Academic Press, 2014), 41-67.

civ It should be noted that while 'cultural industry' and 'creative industry' are often used interchangeably, 'cultural' has been favored over 'creative' in the description of contemporary cultural industries and economy for this paper, borrowing Justin O'Connor's definition of 'cultural economy' as being 'concerned [with] understand[ing] how 'the economy' is culturally constructed'. Justin O'Connor, "Intermediaries and Imaginaries in the Cultural and Creative Industries," Regional Studies, 49 no. 3 (2015): 375.

${ }^{\mathrm{cv}}$ David Hesmondhalgh, The Cultural Industries, ${ }^{\text {rd }}$ edition, (London: Sage, 2015): 6.

${ }^{c v i}$ Hesmondhalgh, The Cultural Industries, 16.

cvii Sarah Brouillette, Literature and the Creative Economy, (Stanford: Stanford University Press, 2014): 8.

cviii Brouillette, Literature and the Creative Economy, 8.

cix Murray, "Publishing Studies," 17.

cx Murray, "Publishing Studies," 12. 
Aprhys, Alison. Careers in Publishing and Bookselling: Short Cuts to Getting the Job You Want. Sydney: Hale \& Iremonger, 1997.

Bartscher-Finzer, Susanne. "Proactivity and the Entrepreneurial Self-Concept of Book Publishers." In Publishing Means Business : Australian Perspectives, edited by Aaron Mannion, Millicent Weber, and Katherine Day. Sydney: Monash University Publishing, 2017.

Baverstock, Alison. How to Market Books. 5th ed. Abingdon: Routledge, 2015.

Berens, Kathi. "Judy Malloy's Seat at the (Database) Table: A Feminist Reception History of Early Hypertext Literature." Literary and Linguistic Computing 29, no. 3 (2014): 340-48.

Bhaskar, Michael. Curation: The Power of Selection in a World of Excess. London: Piatkus, 2016.

- The Content Machine: Towards a Theory of Publishing from the Printing Press to the Digital Network. London: Anthem Press, 2013.

Blair, Laura. "Reading and Reviewing in the Digital Era: Examining Readers and Reader

Response Using Goodreads.Com." In SHARP. Victoria, CA, 2017.

Bond Potter, Claire, and Renee C. Romano. Doing Recent History: On Privacy, Copyright, Video Games, Institutional Review Boards, Activist Scholarship, and History That Talks Back. Athens: University of Georgia Press, 2012.

Boswell, Daniel. "What We Write About When We Write About Publishing: Interscript, a Journal for Students of Publishing." Interscript (blog), March 13, 2017.

https://www.interscriptjournal.com/online-magazine/what-we-write-about-when-we-writeabout-publishing.

Branagh-Miscampbell, Maxine, and Stevie Marsden. "The Commodification of the Ideal Young Female Reader in the 21st Century: Zoella Book Club, A Case Study." In SHARP. Victoria, CA, 2017.

Brouillette, Sarah. Literature and the Creative Economy. Stanford: Stanford University Press, 2014.

- Postcolonial Writers and the Global Literary Marketplace. London: Palgrave Macmillan, 2007.

Brown, Stephen. Consuming Books: The Marketing and Consumption of Literature. Oxford: Routledge, 2006.

Bruns, Axel, and Katrin Weller. "Twitter as a First Draft of the Present: And the Challenges of Preserving It for the Future." In Proceedings of the 8th ACM Conference on Web Science, 183-89. Hannover, Germany, 2016.

Bullock, Adrian. Book Production. Oxon: Routledge, 2012.

Burke, Jr., Alexander J. "College of the Book: Teaching Publishing Studies to Undergraduates." Logos 17, no. 2 (2006).

Canty, Nick, and Jamie Criswell. "Deconstructing Social Media: An Analysis of Twitter and Facebook Use in the Publishing Industry." Publishing Research Quarterly 30, no. 4 (2014): 352-76. https://doi.org/10.1007/s12109-014-9376-1.

Chambers, Claire. "Multi-Culti Nancy Mitfords and Halal Novelists: The Politics of Marketing." Textus 23, no. 2 (2010): 389-403.

Chartier, Roger. Forms and Meanings: Texts, Performances, and Audiences from Codex to Computer. Pennsylvania: University of Pennsylvania Press, 1995.

Clark, Giles, and Angus Phillips. Inside Book Publishing. 5th ed. Oxon: Routledge, 2014.

Darnton, Robert. "What Is the History of Books?" Daedalus, 1982, 65-83.

Dessauer, John P. Book Publishing: A Basic Introduction. 3rd ed. New York: Continuum, 1989.

Driscoll, Beth. "Sentiment Analysis and the Literary Festival Audience." Continuum 29, no. 6 (2015): 861-73. 
Driscoll, Beth, and Ken Gelder. "Readers of Popular Fiction and Emotion Online." In New Directions in Popular Fiction: Genre, Distribution, Reproduction, 425-49. London: Palgrave Macmillan, 2016.

Driscoll, Beth, and Claire Squires. "Serious Fun: Gaming the Book Festival." In SHARP. Victoria, CA, 2017.

Finkelstein, David, ed. Edinburgh History of the Book in Scotland, Volume 4: Professionalism and Diversity 1880-2000. Vol. 4. Edinburgh: Edinburgh University Press, 2007.

Fowler, Corinne. "Publishing Manchester's Black and Asian Writers." In Postcolonial Manchester: Diaspora Space and the Devolution of Literary Culture, edited by Corinne Fowler, Robert H Crawshaw, and Lynne Pearce, 79-110. Manchester: Manchester University Press, 2013.

Fraser, Robert, and Mary Hammond, eds. Books without Borders. Vol. 1. London: Palgrave Macmillan, 2008.

Frost, Simon. "Bespoke Bookselling for the Twenty-First Century: John Smith's and Current UK Higher Education." Book 2.0 5, no. 1-2 (2015): 39-57.

Galey, Alan. "The Enkindling Reciter: E-Books in the Bibliographical Imagination.” Book History 15, no. 1 (2012): 210-47.

Geiser, Elizabeth A., Arnold Dolin, and Gladys S. Topkis, eds. The Business of Book Publishing: Papers by Practitioners. London: Westview, 1985.

Gitelman, Lisa. Paper Knowledge: Toward a Media History of Documents. Durham: Duke University Press, 2014.

Graham, Gordon. As I Was Saying: Essays on the International Book Business. London: H. Zell, 1994.

Helgason, Jon, Sara Kärrholm, and Ann Steiner, eds. Hype: Bestsellers and Literary Culture. Lund: Nordic Academic Press, 2014.

Henningsgaard, Per. "Emerging from the Rubble of Postcolonial Studies: Book History and Australian Literary Studies." Ilha Do Desterro 69, no. 2 (2016): 117-26.

_. "Outside Traditional Book Publishing Centres: The Production of a Regional Literature in Western Australia." University of Western Australia, 2008.

Hesmondhalgh, David. The Cultural Industries. 3rd ed. London: Sage, 2015.

"History." University of Pretoria. History (blog), 2017. http://www.up.ac.za/en/informationscience/article/47918/history.

Hjorth-Andersen, Christian. "Publishing." In A Handbook of Cultural Economics, edited by Ruth Towse. Cheltenham: Edward Elgar, 2011.

Jockers, Matthew L. Macroanalysis: Digital Methods and Literary History. Urbana: University of Illinois Press, 2013.

Johnson, Miriam J. "The Rise of the Citizen Author: Writing Within Social Media." Publishing Research Quarterly 33, no. 2 (2017): 131-46.

Kirschenbaum, Matthew. Mechanisms: New Media and the Forensic Imagination. Cambridge: MIT Press, 2008.

- Track Changes: A Literary History of Word Processing. Cambridge: Cambridge University Press, 2016.

Kirschenbaum, Matthew, and Sarah Werner. "Digital Scholarship and Digital Studies: The State of the Discipline." Book History 17, no. 1 (2014): 406-58.

Kovač, Miha. "Reading the Texts on Book Publishing: A New Body of Knowledge about an Old Body of Knowledge." Publishing Research Quarterly 23, no. 4 (2007): 241-53.

—. "The Issue of Publishing Education." Logos, no. 3 (2008).

Kovač, Miha, and Claire Squires. "Scotland and Slovenia." Logos 25, no. 4 (2014): 7 - 19. https://doi.org/10.1163/1878-4712-11112054. 
Laing, Audrey, and Jo Royle. "Marketing and the Bookselling Brand: Current Strategy and the Managers' Perspective." International Journal of Retail \& Distribution Management 34, no. 3 (2006): 198-211.

Mack, Edward. Manufacturing Modern Japanese Literature: Publishing, Prizes and the Ascription of Literary Value. Durham: Duke University Press, 2010.

Marsden, Stevie. "Positioning Publishing Studies in the Cultural Economy." Interscript (blog), June 13, 2017. https://www.interscriptjournal.com/online-magazine/positioning-publishingstudies-in-the-cultural-economy.

_. "The Saltire Society Literary Awards, 1936-2015: A Cultural History." University of Stirling, 2016.

Martens, Marianne. Publishers, Readers, and Digital Engagement. Palgrave Macmillan, 2016.

Maxwell, John W. "Publishing Education in the 21st Century and the Role of the University." Journal of Electronic Publishing 17, no. 2 (2014).

McCleery, Alistair, David Finkelstein, and Jennie Renton, eds. An Honest Trade: Booksellers and Bookselling in Scotland. Edinburgh: John Donald Publishers, 2009.

McCleery, Alistair, and Melanie Ramdarshan Bold. "What Is My Country?: Supporting Small Nation Publishing." Journal of Irish and Scottish Studies 6, no. 1 (2012): 115-31.

Miall, David S. "Empirical Approaches to Studying Literary Readers: The State of the Discipline." Book History 9, no. 1 (2006): 291-311.

Moody, Nickianne, and Nicole Matthews, eds. Judging a Book by Its Cover: Fans, Publishers, Designers, and the Marketing of Fiction. Hampshire: Ashgate Publishing, Ltd, 2007.

Mroczek, Eva. "Thinking Digitally About the Dead Sea Scrolls: Book History Before and Beyond the Book." Book History 14, no. 1 (2011): 241-69.

Murray, Simone. "Charting the Digital Literary Sphere." Contemporary Literature 56, no. 2 (2015): 311-39.

_. "Publishing Studies: Critically Mapping Research in Search of a Discipline." Publishing Research Quarterly 22, no. 4 (2006): 3-25.

Nakamura, Lisa. "“Words with Friends': Socially Networked Reading on Goodreads.” PMLA 128, no. 1 (2013): 238-243. https://doi.org/10.1632/pmla.2013.128.1.238.

Noël, Sophie. "Publishing Studies: The Search for an Elusive Academic Object." Libellarium: Journal for the Research of Writing 8, no. 1 (2015): 139-45. https://doi.org/10.15291/libellarium.v8i1.221.

Noorda, Rachel. "From Waverley to Outlander: Reinforcing Scottish Diasporic Identity through Book Consumption." National Identities, 2017, 1-17. https://doi.org/doi.org/10.1080/14608944.2016.1271781.

- "The Power of the Small Press: Entrepreneurial Publishing and Disruption of the Industry." TXT, no. 1 (2016): 87-93.

O'Connor, Justin. "Intermediaries and Imaginaries in the Cultural and Creative Industries." Regional Studies 49, no. 3 (2015): 374-87.

Orton, Marie. "Writing the Nation: Migration Literature and National Identity." Italian Culture 3, no. 1 (2012): 21-37.

Osmond, Gary. "Tweet out? Twitter, Archived Data, and the Social Memory of out LGBT Athletes." Journal of Sport History 44, no. 2 (2017): 322-35.

Owen, Lynette. Selling Rights. 7th ed. Abingdon: Routledge, 2014.

Owen, Peter, ed. Publishing Now. London: Peter Owen, 1993. , ed. Publishing-The Future. London: Peter Owen, 1988.

Pickford, Susan. "The Booker Prize and the Prix-Goncourt: A Case Study of Award-Winning Novels in Translation." Book History 14, no. 1 (2011): 221-40.

Ponzanesi, Sandra. The Postcolonial Cultural Industry: Icons, Markets, Mythologies. London: Palgrave Macmillan, 2014. 
Ramdarshan Bold, Melanie. "The Return of the Social Author Negotiating Authority and Influence on Wattpad." Convergence: The Journal of Research into New Media Technologies 24, no. 2 (2016): 117-36. https://doi.org/10.1177/1354856516654459.

Ray Murray, Padmini, and Claire Squires. "The Digital Publishing Communications Circuit." Book 2.0 3, no. 1 (2013): 3-23.

Rehberg Sedo, DeNel, and Danielle Fuller. "Fun...And Other Reasons for Sharing Reading With Strangers: Mass Reading Events and the Possibilities of Pleasure." In Plotting the Reading Experience: Theory/Practice/Politics, edited by Lynne (E.F.) McKechnie, Knut Oterholm, Paulette M. Rothbauer, and Kjell Ivar Skjerdingstad, 133-47. Waterloo: Wilfrid Laurier University Press, 2016.

Roberts, Gillian. Prizing Literature: The Celebration and Circulation of National Culture. Toronto: University of Toronto Press, 2011.

Romano, Renee C., and Claire Bond Potter. "Just over Our Shoulder: The Pleasures and Perils of Writing the Recent Past." In Doing Recent History : On Privacy, Copyright, Video Games, Institutional Review Boards, Activist Scholarship, and History That Talks Back, edited by Renee C. Romano and Claire Bond Potter. Athens: University of Georgia Press, 2012. Rowberry, Simon. "Ebookness." Convergence: The Journal of Research into New Media Technologies 23, no. 3 (2017): 289-305.

_. "Modelling the Book: Amazon's Patents and the Book as Technology." In SHARP. Victoria, CA, 2017.

Rowland, Fytton. "Degree Courses in Publishing at British Universities." Serials 13, no. 3 (2003): 167-73. https://doi.org/10.1629/13167.

Rubery, Matt. The Untold History of the Talking Book. Cambridge: Harvard University Press, 2016.

Ry-Kottoh, Lucy. "Publishing Studies as an Academic Discipline or Professional Programme: An African Perspective." Florence, Italy, 2015.

Schouten, John W., and James H. McAlexander. "Subcultures of Consumption: An Ethnography of the New Bikers." Journal of Consumer Research 22, no. 1 (1995): 43-61.

Shep, Sydney. "Books Without Borders: The Transnational Turn in Book History." In Books Without Borders, edited by Robert Fraser and Mary Hammond, Vol. 1. London: Palgrave Macmillan, 2008.

Smith, Kelvin. The Publishing Business: From p-Books to e-Books. London: AVA Publishing, 2012.

Squires, Claire. Marketing Literature: The Making of Contemporary Writing in Britain. London: Palgrave Macmillan, 2007. . "Publishing's Diversity Deficit." CAMEo Cuts, no. 2 (2017).

Steiner, Ann. "Serendipity, Promotion, and Literature: The Contemporary Book Trade and International Megasellers." In Hype: Bestsellers and Literary Culture, edited by Jon Helgason, Sara Kärrholm, and Ann Steiner, 41-67. Lund: Nordic Academic Press, 2014.

Striphas, Ted. The Late Age of Print: Everyday Book Culture from Consumerism to Control. New York: Columbia University Press, 2009.

Tebbel, John. "Education for Publishing." Library Trends, Fall 1984, 223-33.

Thompson, John B. Merchants of Culture: The Publishing Business in the Twenty-First Century. John Wiley \& Sons, 2013.

Throsby, David. "Commerce or Culture? Australian Book Industry Policy in the Twenty-First Century." In Publishing Means Business : Australian Perspectives, edited by Katherine Day, Aaron Mannion, and Millicent Weber, 1-21. Sydney: Monash University Publishing, 2017.

Travis, Trysh. "The Women in Print Movement: History and Implications." Book History 11, no. 1 (2008): 275-300.

Unwin, Stanley. The Truth About Publishing. New York: Houghton Mifflin Co., 1926. 
Weber, Millicent. "Conceptualizing Audience Experience at the Literary Festival." Continuum: Journal of Media and Cultural Studies 29, no. 1 (2015): 84-96.

Weber, Millicent, Aaron Mannion, and Katherine Day, eds. Publishing Means Business: Australian Perspectives. Melbourne: Monash University Publishing, 2017. 